\title{
Occupational Stress and Work Capacity of Nurses of a Hospital Group ${ }^{1}$
}

\author{
Christian Negeliskii \\ Liana Lautert ${ }^{3}$
}

The study aimed to evaluate the relationship between occupational stress and the work capacity index of 368 nurses ( $82.1 \%$ of the population) of a Hospital Group. A questionnaire with socio-occupational questions was used as well as two scales: the Job Stress Scale and the Work Capacity Index. The group of nurses was predominantly female (93.2\%), worked in care activities (63.9\%), had undertaken at least one Postgraduate course (76\%) and were satisfied with the unit where they worked $(70.5 \%)$. Occupational stress was present in 23.6\% of the nurses, of these $15.2 \%$ presented High Strain work and 8.4\% Passive Work. Social Support exercised a significant positive influence on all groups - exposed or not to occupational stress. Regarding the Work Capacity, this was Moderate (28-36 points) for $51.4 \%$ of the nurses and Good (37-43 points) for $47.4 \%$. There was no correlation between stress and work capacity.

Descriptors: Stress, Physiological; Nurses, Male; Occupational Health; Working Conditions; Nursing Research.

\footnotetext{
${ }^{1}$ Paper extracted from Master's Dissertation "O estresse laboral e capacidade para o trabalho de enfermeiros no Grupo Hospitalar Conceição", presented to Programa de Pós-Graduação em Enfermagem, Escola de Enfermagem, Universidade Federal do Rio Grande do Sul, Porto Alegre, RS, Brazil.

${ }^{2}$ RN, Specialist in Intensive Care, Grupo Hospitalar Conceição, Porto Alegre, RS, Brazil. Professor, Centro Universitário FEEVALE, Porto Alegre, RS, Brazil. E-mail: chnegel@feevale.br.

${ }^{3}$ RN, Ph.D. in Psychology. Associate Professor, Escola de Enfermagem, Universidade Federal do Rio Grande do Sul, Porto Alegre, RS, Brazil. E-mail: lila@enf.ufrgs.br.
}

Corresponding Author:

Christian Negeliskii

Centro Universitário FEEVALE. Instituto de Ciências da Saúde

Curso de Enfermagem

Campus II RS 239, no 2755

Vila Nova

CEP: 93352-000 Novo Hamburgo, RS, Brasil

E-mail: chnegel@feevale.br 


\title{
Estresse laboral e capacidade para o trabalho de enfermeiros de um grupo hospitalar
}

Este estudo teve como objetivo avaliar a relação entre o estresse laboral e o índice de capacidade para o trabalho, de 368 enfermeiros (82,1\% da população) de um grupo hospitalar. Utilizou-se um questionário com questões sócio-ocupacionais e duas escalas: a Job Stress Scale e o índice de capacidade para o trabalho. O grupo de enfermeiros era predominantemente feminino (93,2\%), trabalhando em atividades assistenciais $(63,9 \%)$, possuía pelo menos um curso de pós-graduação (76\%) e satisfeito com a unidade onde trabalhava $(70,5 \%)$. O estresse laboral está presente em $23,6 \%$ dos enfermeiros, e, desses, $15,2 \%$ apresentam alta exigência no trabalho e 8,4\% trabalho passivo. 0 apoio social exerce influência positiva significativa sobre todos os grupos - expostos e não expostos ao estresse laboral. Quanto à capacidade para o trabalho, essa é moderada (28-36 pontos) para 51,4\% dos enfermeiros e boa (37-43 pontos) para 47,4\%. Não há correlação entre o estresse e a capacidade para o trabalho.

Descritores: Estresse Fisiológico; Enfermeiros; Saúde do Trabalhador; Condições de Trabalho; Pesquisa em Enfermagem.

\section{Estrés laboral y capacidad para el trabajo de enfermeros de un grupo hospitalario}

\begin{abstract}
Se trata de un estudio con objetivo de evaluar la relación entre el estrés laboral y el índice de capacidad para el trabajo de 368 enfermeros (82,1\% de la población) de un Grupo Hospitalario. Se utilizó un cuestionario con cuestiones socio ocupacionales y dos escalas: la Job Stress Scale y el Índice de Capacidad para el Trabajo. El grupo de enfermeros es predominantemente femenino (93,2\%), trabaja en actividades asistenciales (63,9\%), posee por lo menos un curso de posgraduación (76\%) y está satisfecho con la unidad donde trabaja (70,5\%). El estrés laboral está presente en $23,6 \%$ de los enfermeros, de estos $15,2 \%$ presentan Alta Exigencia en el trabajo y 8,4\% Trabajo Pasivo. El Apoyo Social ejerce influencia positiva significativa sobre todos los grupos expuestos y no expuestos al estrés laboral. En cuanto a la Capacidad para el Trabajo, está es Moderada (28-36 puntos) para 51,4\% de los enfermeros y Buena (37-43 puntos) para $47,4 \%$. No se encontró correlación entre el estrés y la capacidad para el trabajo.
\end{abstract}

Descriptores: Estrés Fisiológico; Enfermeros; Salud Laboral; Condiciones de Trabajo; Investigación en Enfermería.

\section{Introduction}

Stress is currently a common term and features in the quotidian of health professionals. Reports from nurses, who feel stressed, are verbalized daily in the reality of a teaching hospital of Porto Alegre, confirming nursing as the fourth most stressful of occupations(1). Furthermore, the increasing occurrence of absences from work for health reasons has caused concern among managers and colleagues, faced with the effects this generates in the work quotidian. From May 2007 until April 2008, according to data provided by the personnel department of this institution, there were 782 sick leave incidences of nurses. These amounted to 1,087 days of medical certificated absenteeism (leave of up to 15 days) and 676 days of absences over 15 days, where nurses had to contact the National Social Security Institute. At this time the institution had 456 nurses on the staff, who had a mean of 1.71 days of medical certificate absences and 3.86 days of sick leave of over 15 days in the year. The majority of absences were due to problems that could result from stress, such 
as immunological, osteomuscular, cardiovascular and gastrointestinal disorders ${ }^{(2-3)}$. When viewing stress as injurious to the health of the nurses in this institution, there is motivation to investigate elements with the potential to trigger stress, in order to obtain subsidies to introduce actions to preserve the work capacity and quality of life ${ }^{(2)}$ of these professionals.

An individual is subjected to stress when they need to face demands that they evaluate as greater than their resources, in a way that they cannot produce an effective response $^{(3)}$. In such a situation, the body emits a response to stress, with a significant increase in physiological, cognitive and motor activation. The consequences of this activation depend on the duration and intensity of the stressor event. Thus, when the stress response is frequent and intense, it may adversely impact, with psychosomatic or psychophysiological manifestations. Occupational stress in turn refers to the stimulus of the working environment and aversive responses faced with these stimuli(3). In this state, the person may establish interpersonal relationships permeated by conflict, making the workplace a tensioning scenario of the human, social and hierarchical relationships. The maintenance of the physical and mental health of the person or their illness is related to the interpretation of the outside world and to the resources at their disposal to meet the demands and the stimuli to which they are exposed. The greater the comprehension and control of the pressures and situations that influence the person, the better the produced adaptation and responses will be. However, if the occupational stress predominates, its effect on the individual will be negative, discouraging the conduct of their duties, provoking feelings of loneliness, impotence, and despondency ${ }^{(2)}$ and diminishing their work capacity, which is defined as how well the employee is and how capable they can perform their job, according to the requirements, to their health status and to their physical and mental resources ${ }^{(4)}$. Thus, the healthcare services of the worker should have the attention focused on both employee participation in matters relating to their health, as well as on the social, political, and historic determination dynamics, considering that the association of these elements influences the work capacity and the health-sickness process $^{(4)}$. In this perspective, these services should develop promotional and health monitoring activities and stimulate the construction of conduct aimed at the well-being of the individuals and the adoption of a model of healthy living.

Therefore, the health professionals themselves and the institutions should create mechanisms to analyze the capacity of the workers in the different realities. For this, some instruments have been constructed, among which is the of the Work Capacity Index (WCI), which evaluates the capacity of the worker to perform their work, and can predict the risk of incapacity in the near future ${ }^{(4)}$. Its authors recommend that it is re-applied periodically in order to monitor the evolution of the health of the worker. Therefore, this study was carried out to evaluate the relationship between the occupational stress of nurses working in a Hospital Group and their capacity to perform the work.

\section{Method}

This is a descriptive study with a quantitative approach. The study site was a Hospital Group (HG), located in Porto Alegre, in the State of Rio Grande do Sul, Brazil. The HG, which consists of four hospitals and 12 primary health units (PHU), is an institution for care, teaching and research focused exclusively on the care of patients within the Brazilian National Health System. The HG has 1,490 beds and 7,300 employees, of whom 502 are nurses. The study employed a census sample which included all of the 448 nurses who were performing their usual functions in the HG, in July 2009. Of these $34(7.6 \%)$ did not return the questionnaire, $45(10.1 \%)$ refused to participate in the study and one $(0.2 \%)$ was excluded due to inadequate filling of the questionnaire. At the end of this data collection the sample was composed of 368 nurses $(82.1 \%$ of the population). For the data collection a questionnaire consisting of questions to characterize the subjects was used, as well as the Job Stress Scale (JSS) to measure the stress of nurses and the Work Capacity Index (WCI). The JSS is a reduced version of the Karasek Job Content Questionnaire, designed in Sweden by Tores Theorell in 1988, containing 17 questions - five to evaluate demand, six for control and six for social support ${ }^{(5)}$.

The Demand-Control model in the study evaluates the work demand (a construct related to stress) and the control of activity (a dimension that evaluates the aspects concerning the use of skills and the decisionmaking authority regarding the work). The Social Support evaluates the work environment, the kind of support received from the immediate supervisors as well as the colleagues. The model was categorized into four quadrants: Passive Work (low demands and low control); Active Work (high demands and high control), High Strain (high demands and low control) and Low Strain (low demands and high control). The values that do not 
fall into low or high are classified in the Intermediate group. Stress arises when individuals face High Strain, i.e. high work demands with reduced control to cope with them. Passive Work can also provoke harmful health problems due to the decline in learning, the gradual loss of previously acquired skills and disinterest in the professionals affected ${ }^{(6-7)}$.

The other scale used was the WCI which evaluates seven aspects: 1) the person's current work capacity compared with the best of their life; 2 ) the work capacity compared with the work demands; 3) total number of self-perceived diseases diagnosed by the physician; 4) estimated loss of work due to illness; 5) absence from work due to illness; 6) self prognosis of work capacity; and 7) mental resources. The results can vary between a score of seven to 49 points, with a score of seven to 27 classified as the group with Low work capacity, 28 to 36 with Moderate capacity, 37 to 43 Good, and 44 to 49 with Excellent work capacity. The results can be used collectively or individually(4).

Data collection was conducted from March to August 2009, by the researcher through individual invitations to the nurses of the institution, with the delivery of the Terms of Free Prior Informed Consent and of the instrument to their respective workplaces. Data analysis was performed using the software Statistical Package for the Social Sciences. Initially, the internal consistency of the three dimensions of the JSS (Demand, Control and Social Support) and of the WCI were calculated, through the Cronbach's alpha correlation coefficient, which estimates the overall consistency of a scale. Values above 0.70 are generally acceptable ${ }^{(8)}$. Next, the descriptive analysis of the study variables (identification data, JSS scores and WCI points) was performed. To test differences between the groups of the JSS and the WCI the chi-square and Mann-Whitney tests were used(8). A visual analogue scale from zero to 100 was also used, to evaluate the satisfaction with the remuneration of the work.

To test the differences between the scores of the JSS groups, the data of the nurses were organized into two groups: non-stressed (Low Strain and Active Work) and stressed (High Strain and Passive Work). Regarding the WCI data, due to the low percentage of nurses with Low and Excellent work capacity, the data were grouped into two groups - Low/Moderate Capacity and Good/ Excellent Capacity - in order to perform the statistical tests. From this allocation, the differences were tested between the distributions of the nurses according to the other variables studied.
The research project was approved by the Research Ethics Committee of the institution under study, under number 247/08, on February 11, 2009. The study complied with the criteria set out in resolution 196/96 of the National Health Council, ensuring the rights and obligations with respect to the scientific community and the study subjects ${ }^{(9)}$.

\section{Results}

Initially the internal consistency of the scales was calculated, using Cronbach's alpha. The Job Stress Scale presented 0.72 in the dimension Demand, 0.65 in Control and 0.77 in Social Support; The Work Capacity Index obtained an alpha of 0.77 . The characterization of the participants showed the prevalence of females (93.2\%), with $64.8 \%(n=237)$ married or with a partner. The mean age was 40.7 years (SD 9.4), with the mean time since graduation of 14.6 years (SD 8.9), and the mean time working in the institution of 10.9 years (SD 9.8).

Table 1 - Distribution of nurses according to site of work and occupational characteristics. Porto Alegre, Brazil, 2009

\begin{tabular}{|c|c|c|}
\hline Variables & $\mathbf{n}$ & $\%$ \\
\hline \multicolumn{3}{|l|}{ Group $(n=360)^{*}$} \\
\hline Hospital 1 & 178 & 49.4 \\
\hline Hospital 2 & 58 & 16.1 \\
\hline Hospital 3 & 68 & 18.9 \\
\hline Hospital 4 & 28 & 07.8 \\
\hline Primary Health Units & 28 & 07.8 \\
\hline \multicolumn{3}{|l|}{ Function in the institution $(366)^{*}$} \\
\hline Care & 234 & 63.9 \\
\hline Administrative & 35 & 09.6 \\
\hline Both & 97 & 26.5 \\
\hline \multicolumn{3}{|l|}{ Unit of work $(n=357)^{*}$} \\
\hline Open (26= PHU and 168= Hospital) & 194 & 54.3 \\
\hline Closed & 139 & 38.9 \\
\hline Mixed & 24 & 06.7 \\
\hline \multicolumn{3}{|l|}{ Unit of work $(n=316)^{*}$} \\
\hline Adult & 168 & 53.2 \\
\hline Pediatric & 63 & 19.9 \\
\hline Mixed & 85 & 26.9 \\
\hline \multicolumn{3}{|l|}{ Work in another institution (368)* } \\
\hline No & 306 & 83.2 \\
\hline
\end{tabular}

* The calculation included only the nurses who answered this question.

The nurses that work 36 hours per week were satisfied with the remuneration, which obtained a mean of 69.3 points with an SD of 18.4 , on a scale of zero to 100 . The majority of the professionals (54.3\%) operated in the open units. 
Table 2 - Satisfaction of the nurses with the institution and the work. Porto Alegre, Brazil, 2009

\begin{tabular}{|c|c|c|}
\hline Variables & $\mathbf{n}$ & $\%$ \\
\hline \multicolumn{3}{|c|}{ Number of people in the work scale $(362)^{*}$} \\
\hline Sufficient & 184 & 50.8 \\
\hline \multicolumn{3}{|c|}{ Daily activities are routine and repetitive $(366)^{\star}$} \\
\hline Frequently & 83 & 22.7 \\
\hline Sometimes & 200 & 54.6 \\
\hline Rarely & 68 & 18.6 \\
\hline Never or almost never & 15 & 4.1 \\
\hline \multicolumn{3}{|c|}{ Received training during the previous year $(365)^{*}$} \\
\hline Frequently & 131 & 35.9 \\
\hline Sometimes & 153 & 41.9 \\
\hline Rarely & 64 & 17.5 \\
\hline Never or almost never & 17 & 4.7 \\
\hline \multicolumn{3}{|l|}{ Have time for leisure $(368)^{*}$} \\
\hline Frequently & 155 & 42.1 \\
\hline Sometimes & 174 & 47.3 \\
\hline Rarely & 34 & 9.2 \\
\hline Never or almost never & 05 & 1.4 \\
\hline \multicolumn{3}{|c|}{ Feel satisfied with the site of work $(366)^{*}$} \\
\hline Frequently & 258 & 70.5 \\
\hline Sometimes & 101 & 27.6 \\
\hline Rarely & 07 & 1.9 \\
\hline \multicolumn{3}{|c|}{ Feel valued in the institution of work $(365)^{*}$} \\
\hline Frequently & 95 & 26.0 \\
\hline Sometimes & 196 & 53.7 \\
\hline Rarely & 58 & 15.9 \\
\hline Never or almost never & 16 & 4.4 \\
\hline \multicolumn{3}{|c|}{ The organization of the work unit is good $(363)^{*}$} \\
\hline Frequently & 163 & 44.9 \\
\hline Sometimes & 162 & 44.6 \\
\hline Rarely & 31 & 8.5 \\
\hline Never or almost never & 07 & 1.9 \\
\hline
\end{tabular}

* The calculation included only the nurses who answered this question.

Regarding post-graduate courses taken by the nurses of the HG, it was found that 279 (76\%) had completed at least one post-graduate course, of which $30 \%$ had taken two or more courses. Among the courses, $7.69 \%$ were MSc courses and the others Lato Sensu in the areas: hospital (24.45\%), administration (23.08\%), collective health $(10.99 \%)$, pediatrics (7.69\%), education (4.39\%), mental health (1.39\%) and general specializations ( $11.26 \%)$.

The organization of work units of the HG, despite presenting some variations from one sector to another, was considered satisfactory by $44.9 \%$ of the nurses. It is also important to note that $70.5 \%$ of these professionals feel satisfied with the site where they work. However, only $26 \%$ feel frequently valued in the Institution in which they work, i.e. in the HG.
Table 3 - Distribution of the nurses according to the quadrants of the Karasek's Demand-Control Model. Porto Alegre, Brazil, 2009

\begin{tabular}{|c|c|c|c|c|c|}
\hline \multirow{2}{*}{$\begin{array}{l}\text { Quadrants of } \\
\text { Karasek's model }\end{array}$} & \multirow{2}{*}{$\mathbf{n}$} & \multirow{2}{*}{$\%$} & \multicolumn{2}{|c|}{ Social Support } & \multirow{2}{*}{$p$-value * } \\
\hline & & & Mean & SD & \\
\hline Low strain & 76 & 20.7 & 18.5 & 2.3 & 0.000 \\
\hline Active work & 159 & 43.2 & & & \\
\hline High strain & 56 & 15.2 & 16.7 & 3.3 & 0.000 \\
\hline Passive work & 31 & 08.4 & & & \\
\hline Intermediates & 46 & 12.5 & & & \\
\hline Total & 368 & 100 & & & \\
\hline
\end{tabular}

* Mann-Whitney nonparametric test to compare groups.

The nurses of the High Strain /Passive Work group, denominated the 'stressed group', perceive less Social Support from their colleagues and managers, compared with the Low Strain/Active Work group, a factor that can increase the stress experienced or be a generator of this.

Table 4 - Distribution of the nurses according to the Work Capacity Index- WCI. Porto Alegre, Brazil, 2009

\begin{tabular}{lccc}
\hline \multicolumn{1}{r}{ WCI classification } & Scores & $\mathbf{n}$ & $\%$ \\
\hline Low & $07-27$ & 02 & 0.6 \\
Moderate & $28-36$ & 186 & 51.4 \\
Good & $37-43$ & 172 & 47.4 \\
Excellent & $44-49$ & 02 & 0.6 \\
Total & & 362 & 100.0 \\
\hline
\end{tabular}

Among the nurses of the PHUs, $70.4 \%$ present a Low/Moderate work capacity, 59.4\% work in open units and $57.9 \%$ work with adult patients. Despite the prevalence of nurses with physician diagnosed diseases $(66.3 \%)$, only lesions on the arms and hands showed statistical differences between the Low/Moderate and Good/Excellent work capacity groups $(p<0.05)$.

High Strain /Passive Work (stressed) and Active Work/Low Strain (non-stressed) groups presented no statistical differences with the WCI scores Low/Moderate and Good/Excellent work capacity $(\mathrm{p}<=0.548)$.

In summary, Table 5 shows the work and personal variables that present statistical differences with the groups of the JSS, High Strain/Passive Work and Low Strain/Active Work, and the WCI, Low/Moderate Capacity and Good/Excellent Capacity. The work site classified as an adult or pediatric unit was the only one that showed a difference in both scales. 
Table 5 - Variables that presented statistical differences in the analysis of the JSS and WCI. Porto Alegre, Brazil, 2009

\begin{tabular}{lcc}
\hline & \multicolumn{2}{c}{ p-value* } \\
\cline { 2 - 3 } \multicolumn{1}{c}{ Variables } & JSS & WCI \\
\hline Hospital $(1,2,3,4)$ & 0.462 & 0.027 \\
Post-Graduation (yes, no) & 0.005 & 0.093 \\
Marital status (with and without a partner/spouse) & 0.011 & 0.638 \\
Function in the institution (care or management) & 0.013 & 0.088 \\
Unit of work (open or closed) & 0.358 & 0.015 \\
Unit of work (adult or pediatric) & 0.037 & 0.024 \\
Daily activities are routine and repetitive (yes, no) & 0.003 & 0.763 \\
Received training during the previous year (yes, no) & 0.023 & 0.412 \\
Feel satisfied with the site of work (yes, no) & 0.000 & 0.325 \\
Feel valued in the institution of work (yes, no) & 0.007 & 0.067 \\
Social support (yes, no) & 0.000 & 0.076 \\
\hline
\end{tabular}

p-value obtained by chi-square test of independence $(<0.05)$. * MannWhitney nonparametric test to compare groups.

\section{Discussion}

In analyzing the internal consistency of the scales used in this investigation, the Cronbach's Alpha values of the two are similar to those found in studies with other samples ${ }^{(5,10-11)}$ and ensure the internal consistency and reliability of these instruments for the study sample ${ }^{(8)}$.

The professional qualification of the sample, in which $76 \%$ of the nurses had post-graduate qualifications, was high compared with other studies with nurses $\left(72.72 \%{ }^{(11)}, 50.8 \%^{(12)}\right.$ e $\left.70.8 \%{ }^{(13)}\right)$. However, the other characteristics were similar to those reported in other surveys conducted in public institutions ${ }^{(1,13-14)}$, i.e. showing age and length of service higher than in private institutions ${ }^{(15-16)}$. The 69.3 point measurement of satisfaction with the remuneration was higher than the data from another study (13) which showed this as low and a source of stress. It is inferred that these differences arise from the employment stability provided by the public position and the guaranteed salary, which ratify and encourage the nurses to maintain an employment contract for so many years (mean 10.9, SD 9.8 years).

Regarding the organization of the work units of the HG, this was considered satisfactory by the nurses and $70.5 \%$ felt satisfied with the site where they work, evidencing good management of the different work sites and the importance of the proper allocation of the professionals in the work positions. However, only $26 \%$ felt valued in the institution, a feeling that may be associated with the work environment and the interpersonal relationships ${ }^{(13)}$
The lack of value of the nurses of the sample can be attributed to their lack of participation in the decisionmaking process of the institution, where positions are indicated by the managers, under the influence of the Ministry of Health. Due to this system, the management of the Hospital Group generally changes with every political mandate disrupting the continuity of some actions. These systematic alterations make long-term projects unviable and sometimes disrupt productive actions, leading to the demotivation of the workers.

Concerning the work, $15.2 \%$ of the nurses were considered to have many demands and a low level of control, i.e. with High Strain. Adding this percentage to the $8.4 \%$ with Passive Work (low demands and low control), it can be verified that $23.6 \%$ may be vulnerable to work stress ${ }^{(6)}$ and to present loss of skills or disinterest. Although these percentages are similar to the national literature ${ }^{(11,17)}$, the mean of Social Support perceived by the High Strain and Passive Work groups is lower than that of the Low Strain and Active Work groups ( $p<0.05)$, which can potentialize the stress experienced. Therefore, Social Support can be visualized as an action to be used in order to prevent and/or reduce work stress.

Regarding the site/unit of work in the HG, there was no difference between the scores of the groups who worked in the open or closed units, which differs from several publications that emphasize the stress in closed or specialized units ${ }^{(1,11-12,16,18-20)}$. However, the nurses working in units with adult patients, performing routine and repetitive activities and who did not do any training in the previous year, were more stressed than the others $(p<0.05)$. Also, among the nurses without post-graduate qualifications and those who were married, higher percentages of stress $(p<0.05)$ were found, which leads to the inference that the search for knowledge, prepares the individual to face difficulties at work, relieving the stress, which differs from another study ${ }^{(13)}$, in which the support of the spouse or partner relieved the stress.

Similar to another study(21), there was a higher proportion of nurses in the categories Low Strain and Active Work (77.1\%) developing administrative activities, compared with the care activities group, showing that to assist the patient gives less control of the activity which may be due to fluctuations in the health status and the different demands of this individual, which increases the work demands for these professionals. However, the perception of stress in the work did not affect the measures of the WCI of these nurses $(p<0.548)$ because there was no association between these two scales. This finding may be related to the different constructs that 
evaluate (demand and control in the work versus the perceived capacity to perform the work).

Regarding the work capacity, the data show a higher frequency (52\%) of scores classified as Moderate or Low, a prevalence higher than in other studies, which indicates the need for measures to restore and promote the working competence of these professionals. The first of two studies of nursing teams ${ }^{(15,22)}$, with 387 and 269 workers respectively, identified that $83.2 \%$ of the employees presented Good work capacity and the second identified that $51.7 \%$ presented Good work capacity and $20.1 \%$ Excellent. In an international study, $32.0 \%$ of the subjects reported Moderate capacity ${ }^{(23)}$.

Although age is considered an important factor in determining the work capacity ${ }^{(4,10,24-25)}$, in the present investigation there was no difference $(p<0.54)$ between the proportion of nurses in the different age groups nor between the genders ( $p<0.14$ ), unlike the study of nursing staff that highlights, as well as age, that the lowest scores on the WCI were associated with the female gender ${ }^{(22)}$ and the study that validated the scale ${ }^{(4)}$, which found differences between the scores of the age groups 50, 55 and 58 years, which was did not occur in this study that approached younger individuals (mean age 40.7 years, SD 9.4).

It is also worth noting, the significant difference between the scores of the nurses of open and closed units $(p<0.015)$ and adult and pediatric units $(p<0.024)$, with the open units having a significant percentage of nurses with Low/Moderate WCI (59.4\%) and the pediatric unit nurses with Good/Excellent WCI (60.3\%) Among the open units were nurses from the PHUs, among whom $70.4 \%$ were classified in the group with Low/Moderate WCI. These data lead to the consideration that, as identified in another study(2), these professionals require actions that encourage the promotion of the work capacity, stimulating them to develop clinical and managerial skills. Conversely, in the analysis of the scores of the nurses of Hospital 2 (63.8\% between Good/Excellent), the opposite was observed. The nursing leadership of the hospital is structured and articulated differently to the other units of the Group, which may have influenced the work capacity scores of the nurses.

Through the findings of this investigation, with a large number of professionals with Low and Moderate work capacity (52\%) and occupational stress (23.6\%), it appears that these data may be associated with the physical workload, which increases when the professional autonomy decreases, leading to the appearance of suffering in the work.

\section{Conclusions}

The results of this study highlight the need to restore the state of physical and psychological health of the nurses who work primarily in care activities, in open units, and with adult patients. The strategies outlined are aimed at the valorization of the workers and the investment in ongoing education in health, which may have a protective role in the health of the worker, acting against stressors in the work quotidian, at the same time as providing autonomy to the nursing staff.

Another point to be considered is the Social Support, which may constitute a pillar of the occupational conjuncture and a strategy of social organization in the institutions, in order to prevent and/or to reduce occupational stress, since the valorization of the working relationships, as well as the environment, promotes health benefits for the workers. Thus, proactive attitudes in their roles, the search for the construction of scientific knowledge and recognition, the struggle for better working conditions, and the corporate articulation of the professional category, are elements that can construct the Social Support and strengthen the nurses.

Finally, the aspects considered in the present study are elements that can contribute to the conception and development of measures aimed at preserving the work capacity, prioritizing the monitoring and control of occupational stress with emphasis on the psychosocial work relationships, thus, improving the promotion, the protection and the restoration of the health of the workers

Considering the cross-sectional design of this research, success was obtained with the return of the questionnaires (82.1\%), however, certain difficulties were found to compare it with the literature and to respond to some concerns. Thus, longitudinal studies would be adequate to provide continuity to the evaluation of these variables and to establish causal relationships.

\section{References}

1. Stacciarini JMR, Tróccoli BT. O estresse na atividade ocupacional do enfermeiro. Rev. Latino-Am. Enfermagem. março $2001 ; 9(2): 17-25$.

2. Trindade LL. O estresse laboral da equipe de saúde da família: implicações para a saúde do trabalhador [dissertação de mestrado]. Porto Alegre (RS): Universidade Federal do Rio Grande do Sul; 2007.103 p. 3. Labrador FJ, Crespo M. Estrés: trastornos psicofisiológicos. Madrid: Eudema; 1993. 110 p. 
4. Tuomi K, Ilmarinen J, Jahkola A, Katajarinne L, Tulkki

A. Índice de capacidade para o trabalho. São Carlos: EdUFSCar; 2005. 59 p.

5. Alves MGM, Chor D, Faerstein E, Lopes CS, Werneck GL. Versão resumida "job stress scale": adaptação para o português. Rev Saúde Pública. abr 2004;38(2):16471.

6. Alves MGM. Pressão no trabalho: estresse no trabalho e hipertensão arterial em mulheres no Estudo Pró-Saúde [Tese]. Rio de Janeiro (RJ): Escola Nacional de Saúde Pública;c 2004. 259 p.

7. Peiró JM. Desencadenantes del estrés laboral. Madrid: Eudema; 1993. 93 p.

8. Hulley SB, Cummings ST, Browner WS, Grady DG, Newman TB. Delineando a pesquisa clínica: uma abordagem epidemiológica. 3 ed. Porto Alegre: Artmed; 2008. 384 p.

9. Ministério da Saúde (BR). Conselho Nacional de Saúde. Resolução 196/96. Brasília: Diário Oficial da União; out 1996.

10. Martinez MC, Latorre MRDO. Fatores associados à capacidade para o trabalho de trabalhadores do Setor Elétrico. Cad Saúde Pública. abr. 2009;25(4):761-72.

11. Schmidt DRC, Dantas RAS, Marziale MHP, Laus AM. Estresse ocupacional entre profissionais de enfermagem do bloco cirúrgico. Texto Contexto Enferm. abr-jun. 2009;18(2):330-7.

12. Bianchi ERF. Enfermeiro hospitalar e o stress. Rev Esc Enferm USP. dez 2000;34(4): 390-4.

13. Montanholi LL, Tavares DMS, Oliveira GR. Estresse: fatores de risco no trabalho do enfermeiro hospitalar. Rev Bras Enferm. set./out. 2006;59(5):661-5.

14. Spindola T, Martins ERC. O estresse e a enfermagem: a percepção das auxiliares de enfermagem de uma instituição pública. Esc Anna Nery. jun 2007;11(2):212-9.

15. Raffone AM, Hennington EA. Avaliação da capacidade funcional dos trabalhadores de enfermagem. Rev Saúde Pública. ago 2005;39(4):669-76.

16. Rodrigues $A B$, Chaves EC. Fatores estressantes e estratégias de coping dos enfermeiros atuantes em oncologia. Rev. Latino-Am. Enfermagem jan-fev 2008;16(1):24-8.

17. Amaral TR. Dimensões psicossociais do trabalho da enfermagem e os distúrbios psíquicos menores em unidades críticas [Dissertação]. Florianópolis (SC): Universidade Federal de Santa Catarina; 2006. 114 p.
18. Ferrareze MVG, Ferreira V, Carvalho AMP. Percepção do estresse entre enfermeiros que atuam em terapia intensiva. Acta Paul Enferm. jul-set. 2006;19(3):310-5. 19. Cavalheiro AM, Moura DF Junior, Lopes AC. Estresse de enfermeiros com atuação em unidade de terapia intensiva. Rev. Latino-Am. Enfermagem jan/fev 2008;16(1):29-35.

20. Aquino JM. Estressores no trabalho das enfermeiras em Centro Cirúrgico: conseqüências profissionais e pessoais [Tese]. Ribeirão Preto (SP): Escola de Enfermagem de Ribeirão Preto da Universidade de São Paulo; 2005.154 p.

21. Lautert L. O processo de enfrentamento do estresse no trabalho hospitalar um estudo com enfermeiras. In: Haag GS, Lopes MJM, Schuck JS. A enfermagem e a saúde dos trabalhadores. Goiânia (GO): AB Ed.; 2001. p. 114-40.

22. Moreno LC. Violência e Capacidade para o Trabalho entre trabalhadores de enfermagem [dissertação de mestrado]. Campinas (SP): Universidade Estadual de Campinas; 2003. 221 p.

23. Bethge $M$, Radoschewski MF, Müller-Fahrnow $W$. Work stress and work ability: cross-sectional findings from the German sociomedical panel of employees. Disabil Rehabil. 2009;31(20):1692-9.

24. Walsh IAP, Corral S, Franco RN, Canetti EEF, Alem MER, Coury HJCG. Capacidade para o trabalho em indivíduos com lesões músculo-esqueléticas crônicas. Rev Saúde Pública. abr 2004;38(2):149-56.

25. Bresic J, Knezevic B, Milosevic M, Tomljanovic T, Golubovic R, Mustajbegovic J. Stress and work ability in oil industry workers. Arh Hig Rada Toksikol. 2007;58:399-405.
Received: Feb. 24 2010 Accepted: Mar. $17^{\text {th }} 2011$ 